\title{
Cytotoxic activity of simvastatin in T47D breast cancer cell lines and its effect on cyclin D1 expression and apoptosis
}

\author{
Bayu Putra ${ }^{1}$, Mae Sri Hartati Wahyuningsih ${ }^{2 *}$, Eti Nurwening Sholikhah ${ }^{2}$ \\ ${ }^{1}$ Postgraduate Program in Basic Medical and Biomedical Sciences, ${ }^{2}$ Department of \\ Pharmacology and Therapy, Faculty of Medicine, Universitas Gadjah Mada, Yogyakarta, \\ Indonesia.
}

DOI: http://dx.doi.org/10.19106/JMedSci004901201701

\begin{abstract}
Statins is HMG-CoA inhibitors which used for decreasing plasma cholesterol levels and preventing coronary artery disease. Preclinical and clinical studies showed that statin could decrease the risk of cancer. This study was performed to evaluate the cytotoxic activity of simvastatin on T47D breast cancer cell lines and its effect in cyclin $D_{1}$ expression and apoptosis. This was quasi experiment using post test with non-equivalent control group design. Simvastatin cytotoxic activity was evaluated using MTT assay. Furthermore, the effect of simvastatin on cyclin $D_{1}$ expression and apoptosis were evaluated using flow cytometry using antibody monoclonal anti-cyclin $\mathrm{D}_{1}$ and annexin $\mathrm{V}-\mathrm{Pi}$, respectively. The results showed that simvastatin had cytotoxic activity on T47D breast cancer cell lines with an $\mathrm{IC}_{50}$ value of $25.25 \pm 1.61 \mu \mathrm{g} / \mathrm{mL}$. Moreover, simvastatin in concentration range from 6.31 to $50.5 \mu \mathrm{g} / \mathrm{mL}$ decreased the cyclin D1 expression with an $\mathrm{EC}_{50}$ value of $18.96 \pm 4.42 \mu \mathrm{g} / \mathrm{mL}$ and induced apoptosis with an $\mathrm{EC}_{50}$ value of $26.96 \pm 6.05 \mu \mathrm{g} / \mathrm{mL}$. In conclusion, simvastatin inhibits T47D breast cancer cell growth through reduction of cyclin $\mathrm{D}_{1}$ expression and induction of apoptosis.
\end{abstract}

\section{ABSTRAK}

Statin (HMG-CoA inhibitor) merupakan golongan obat yang digunakan untuk menurunkan kadar kolesterol plasma dan untuk mencegah jantung koroner. Penelitian praklinik dan klinik menunjukkan bahwa terapi statin dapat menurunkan risiko terjadinya kanker. Penelitian ini bertujuan mengkaji aktivitas sitotoksik simvastatin terhadap kultur sel kanker payudara T47D dan efeknya terhadap ekspresi cyclin $\mathrm{D}_{1}$ dan apoptosis. Jenis penelitian ini adalah eksperimenal semu dengan rancangan post test with non equivalent control group. Aktivitas sitotoksi simvastatin diuji dengan metode MTT assay. Selanjutnya efek simvastatin terhadap ekspresi cyclin $\mathrm{D}_{1}$ dan apoptosis dikaji menggunakan flowcytometry menggunakan antibody monoclonal anti-cyclin $\mathrm{D}_{1}$ dan annexin $\mathrm{V}-\mathrm{Pi}$. Hasil penelitian menunjukkan simvastatin mempunyai aktivitas sitotoksik terhadap sel kanker payudara T47D dengan nilai $I_{50}$ sebesar 25,25 $\pm 1,61 \mu \mathrm{g} / \mathrm{mL}$. Simvastatin dengan kisaran konsentrasi 6,31 sampai $50,5 \mu \mathrm{g} / \mathrm{mL}$ mampu menurunkan ekspresi cyclin $\mathrm{D}_{1}$ dengan nilai $\mathrm{EC}_{50}$ sebesar $18,96 \pm 4,42 \mu \mathrm{g} / \mathrm{mL}$ dan menginduksi apoptosis dengan nilai $\mathrm{EC}_{50}$ sebesar $26,96 \pm 6,05 \mu \mathrm{g} / \mathrm{mL}$. Sebagai kesimpulan, simvastatin menghambat pertumbuhan sel kanker payudara T47D dengan menurunkan ekspresi cyclin $\mathrm{D}_{1}$ dan menginduksi apoptosis.

Keywords: simvastatin - cytotoxic activity - cyclin $\mathrm{D}_{1}$ - apoptosis activity - T47D breast cancer cell lines

Corresponding author: maeshw@ugm.ac.id 


\section{INTRODUCTION}

Cancer can be defined as the rapid growth of body cells cause disorders thus growth beyond the limits of necessity and then invade and spread to other parts of the body. Breast cancer is one of the most common cancers that cause death in women in the world. In 2013 Ministry of Health, Republic of Indonesia reported that the prevalence of breast cancer was the second highest in Indonesia, approximately $0.5 \%$ of total population, with the highest prevalence in Yogyakarta Special Region (2.4\%). ${ }^{1}$

Statin (HMG-CoA Inhibitors) is drugs used for decreasing cholesterol level and prevent heart coroner disease. ${ }^{2}$ In Indonesia, $82.3 \%$ patients with hypercholesterolemia still use statin as first choice drug with the most frequently used is simvastatin $(42.8 \%)$ followed by rosuvastatin (27.9\%) and atorvastatin $(19.2 \%))^{3}$ Statin use is associated with $20 \%$ risk reduction of cancer. Statin have protective effect on cancer survivors therapy for more than 4 years. ${ }^{4}$ Cohort study found that using simvastatin in patients diagnosed with breast cancer, could reduce the death rate of breast cancer. ${ }^{5}$

Furthermore, the statins such as fluvastatin, atorvastatin and simvastatin can inhibit cell proliferation associated with decreasing synthesis of DNA and cell cycle arrest in $G_{1}$ and $\mathrm{G}_{2} / \mathrm{M}$ by increasing the expression of p53 and p21 proteins and induces cell death with oxidative stress. ${ }^{6,7}$ Simvastatin could also induce antiproliferative effects and increase expression of caspase 3 in order to stimulate apoptosis. $^{8,9}$ This study was conducted to prove the cytotoxicity of simvastatin against T47D breast cancer cell lines and its effect on cyclin $\mathrm{D}_{1}$ expression and apoptosis.

\section{MATERIALS AND METHODS}

\section{Materials}

Simvastatin, 4-(2-hydrocyethyl)-piperazine-ethane) sulphonic acid (HEPES), RPMI 1640, fetal bovine serum (FBS) 10\%, amphotericin B, penicillin-streptomycin, and trypsin were obtained from Sigma-Aldrich ${ }^{\circledR}$. The T47D breast cancer cell lines was obtained from the Laboratory of Parasitology, Faculty of Medicine, Universitas Gadjah Mada, Yogyakarta. Other materials were doxorubicin (Ebewe), sodium dodecyl sulfate (SDS) $\left(\right.$ Gibco $\left.^{\circledR}\right)$, sodium bicarbonate (Nacalai Tesque), phosphate buffer saline (PBS) $\left(\right.$ Invitrogen $\left.{ }^{\circledR}\right)$, MTT [3-(4,5-dimethylthiazol2-yl)-2.5-diphenyltetrazolium bromide] (Bio Basic Inc. $\left.{ }^{\circledR}\right), \mathrm{HCl}\left(\mathrm{Merck}^{\circledR}\right)$, cyclin D1-PE (A-12) monoclonal antibody (Santa cruz biotechnology, INC), and annexin $\mathrm{V}$ fluos staining kit $\left(\right.$ Roche $\left.^{\circledR}\right)$.

\section{Cytotoxic activity assay}

The T47D breast cancer cell lines at 1 x $10^{5} / \mathrm{mL}$ were plated in 96 well microplate with $100 \mu \mathrm{L}$ each well and incubated for 24 hours in starvated media. One hundred $\mu \mathrm{L}$ of simvastatin solution in concentration 50; $25 ; 12.5 ; 6.25 ; 3.125$; and $1.5625 \mu \mathrm{g} / \mathrm{mL}$ were added in triplicate and then incubated for 24 hours. The media in each well was changed with $100 \mu \mathrm{L}$ new media and $10 \mu \mathrm{L}$ MTT reagent was added in each well and then incubated for 4-6 hours in a $\mathrm{CO}_{2}$ incubator at $37^{\circ} \mathrm{C}$. Followed after incubation, $100 \mu \mathrm{L}$ SDS in $\mathrm{HCl} 10 \%$ was added in each well and incubated at room temperature for 12 hours. The absorbance of each well was recorded using ELISA reader at $\lambda$ of $595 \mathrm{~nm}$. The absorbance of each well was used to calculate the percentages of proliferation inhibition by comparing with the control cells without any compounds. The concentration inhibiting 
$50 \%\left(\mathrm{IC}_{50}\right)$ of the cell lines was determined by probit analysis.

\section{Expression of cyclin $D_{1}$ assay}

The T47D breast cancer cell lines were cultured in 6 well plates at $5 \times 10^{5}$ cells per well. Each well was added with $2000 \mu \mathrm{L}$ of each concentration series of simvastatin $0 ; 6.31$; $12.62 ; 25.25$ and $50.48 \mu \mathrm{g} / \mathrm{mL}$, and $400 \mu \mathrm{L}$ of flowcytometry reagent. Cells suspension was transferred into the flowcytometry-tube through filter (nylon/glass cloth fabrics) using $1 \mathrm{~mL}$ micropipette. The profile of cyclin $\mathrm{D}_{1}$ expression was measured with flowcytometer and analyzed using FASC-Calibur program. Data were displayed in percentage of cyclin $\mathrm{D}_{1}$ expression in each treatment groups. The effect on cyclin $\mathrm{D}_{1}$ expression was assessed on the concentration inhibiting 50\% expression $\left(\mathrm{EC}_{50}\right)$ which determined by probit analysis.

\section{Apoptosis induction assay}

The T47D breast cancer cell lines were cultured at $5 \times 10^{5}$ in 6 well plates. Each well was added with $2000 \mu \mathrm{L}$ from each concentration series of simvastatin $0 ; 6.31 ; 12.62 ; 25.25$ and $50.48 \mu \mathrm{g} / \mathrm{mL}$ and doxorubicin $0.15 \mu \mathrm{g} / \mathrm{mL}$. Solutions were prepared using incubation buffer $10 \mathrm{mM}$ Hepes/NaOH pH 7.4; $140 \mathrm{mM}$ $\mathrm{NaCl}$ and $5 \mathrm{mM} \mathrm{CaCl}$. Labeling solution for sample consisting of 15 to $30 \mu \mathrm{L}$ of annexin $\mathrm{V}$ plus $1.5 \mathrm{~mL}$ of incubation buffer and 30 $\mu \mathrm{L}$ of PI. Incubation cells were placed at the dark room for 10-15 minutes at a temperature of $15-25^{\circ} \mathrm{C}$. Apoptosis was analyzed using FACS-Calibur program to obtain distribution of the survived cell, apoptotic and necrotized cell on all treatment group. The apoptosis induction activity was assessed on the concentration inducing 50\% apoptosis $\left(\mathrm{EC}_{50}\right)$ which determined by probit analysis.

\section{Statistical analysis}

Data of $\mathrm{IC}_{50}$ an $\mathrm{EC}_{50}$ were presented as mean \pm SD. Data of cyclin D1 expression and apoptosis induction were presented as percentage and compared using analysis of variance (ANOVA) followed by post hoc Bonferroni or Tamhane. A p value $<0.05$ was considered as statistically significant.

\section{RESULTS}

\section{Cytotoxic activity assay}

The inhibitory concentration $50 \%\left(\mathrm{IC}_{50}\right)$ of simvastatin and doxorubicin on T47D breast cancer cell lines were $25.25 \pm 1.61$ and $0.15 \pm 0.016 \mu \mathrm{g} / \mathrm{mL}$, respectively (TABLE 1 ). These results showed that simvastatin had cytotoxic activity on T47D breast cancer cell lines, although its activity was lower than that doxorubicin as positive control $(\mathrm{p}<0.05)$. 
TABLE 1 . The percentage of T47D cell lines proliferation inhibition (\%) and the $\mathrm{IC}_{50}(\mathrm{mean} \pm \mathrm{SD})$ of simvastatin and doxorubicin

\begin{tabular}{|c|c|c|c|c|c|c|c|c|}
\hline \multirow{3}{*}{ Drug } & \multirow{3}{*}{$\begin{array}{l}\text { Concentration } \\
\quad(\mu \mathrm{g} / \mathrm{mL})\end{array}$} & \multicolumn{6}{|c|}{ Replication } & \multirow{3}{*}{ Mean $\mathrm{IC}_{50}$} \\
\hline & & \multicolumn{2}{|l|}{1} & \multicolumn{2}{|c|}{2} & \multicolumn{2}{|l|}{3} & \\
\hline & & Inhibition & $\mathrm{IC}_{50}$ & Inhibition & $\mathrm{IC}_{50}$ & Inhibition & $\mathrm{IC}_{50}$ & \\
\hline \multirow[t]{6}{*}{ Simvastatin } & 50 & 89.45 & \multirow{6}{*}{27.03} & 90.44 & \multirow{6}{*}{24.78} & 91.39 & \multirow{6}{*}{23.92} & \multirow{6}{*}{$25.25 \pm 1.61$} \\
\hline & 25 & 51.28 & & 45.73 & & 58.52 & & \\
\hline & 12.5 & 21.25 & & 20.66 & & 20.92 & & \\
\hline & 6.3 & 12.68 & & 26.45 & & 18.60 & & \\
\hline & 3.1 & 1.98 & & 26.22 & & 11.76 & & \\
\hline & 1.6 & 2.46 & & 5.56 & & 9.06 & & \\
\hline \multirow[t]{5}{*}{ Doxorubicin } & 0.25 & 75.71 & \multirow{5}{*}{0.17} & 80.53 & \multirow{5}{*}{0.14} & 80.15 & & \multirow{5}{*}{$0.15 \pm 0.016$} \\
\hline & 0.13 & 38.51 & & 69.17 & & 56.64 & & \\
\hline & 0.06 & 16.19 & & 14.67 & & 5.14 & 0.15 & \\
\hline & 0.03 & 2.46 & & 2.74 & & -6.25 & & \\
\hline & 0.02 & -10.84 & & -9.49 & & -9.02 & & \\
\hline
\end{tabular}

\section{Expression of cyclin $D_{1}$ assay}

The cyclin $\mathrm{D}_{1}$ expression of T47D breast cancer cell line after incubation with simvastatin is presented in FIGURE 1. At the left side showed population of cells that did not express cyclin $\mathrm{D}_{1}$, and the right side showed population of cells that expressed cyclin $\mathrm{D}_{1}$.

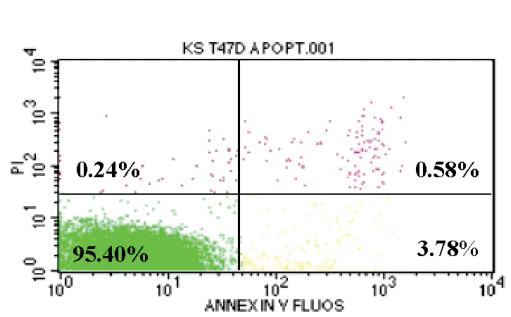

(a)

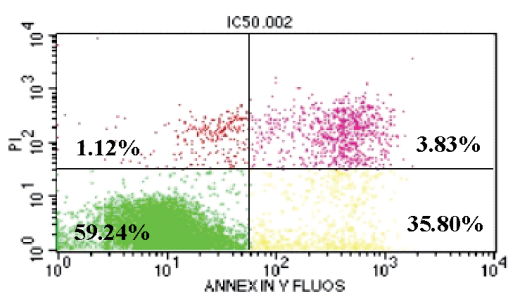

(d)

J Med Sci, Volume 49, No. 2, 2017

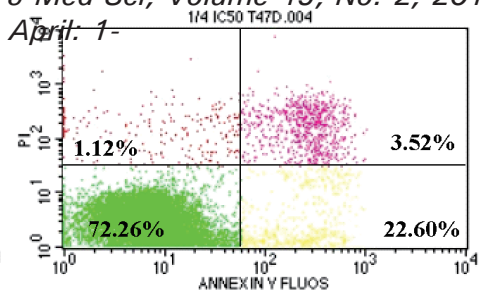

(b)

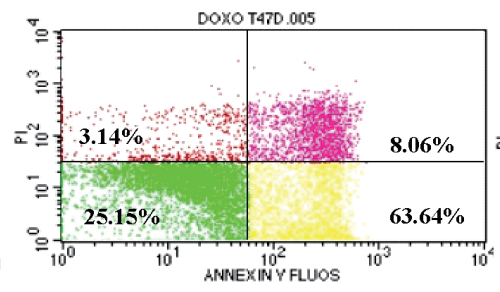

(f)

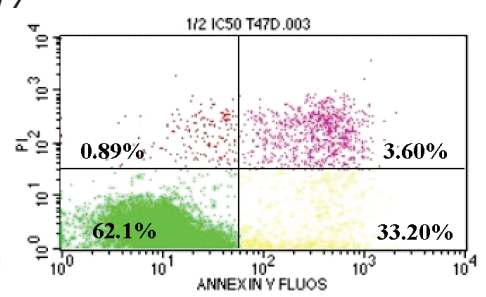

(c)

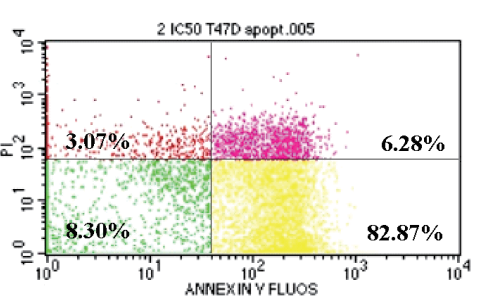

(e)

FIGURE 1. Cyclin D1 expression measured with flowcytometry in (a) control group without simvastatin, (b) simvastatin $6.31 \mu \mathrm{g} / \mathrm{mL}$, (c) simvastatin $12.62 \mu \mathrm{g} / \mathrm{mL}$, (d) simvastatin $25.25 \mu \mathrm{g} / \mathrm{mL}$ (e) simvastatin $50.48 \mu \mathrm{g} / \mathrm{mL}$. 
TABLE 2. Cyclin $\mathrm{D}_{1}$ expression of T47D cells (\%) after incubation with simvastatin for 24 hours.

\begin{tabular}{|l|c|c|c|c|}
\hline \multicolumn{1}{|c|}{ Treatment } & $\begin{array}{c}\text { Concentration } \\
(\mu \mathrm{g} / \mathrm{mL})\end{array}$ & $\begin{array}{c}\text { Cyclin } \mathrm{D}_{1} \text { expression } \\
(\text { Mean } \pm \mathrm{SD} \%)\end{array}$ & $\mathrm{p}$ & $\mathrm{EC}_{50}(\mu \mathrm{g} / \mathrm{mL})$ \\
\hline Control & 0 & $65.89 \pm 0.73$ & & \\
\hline Simvastatin & 6.31 & $59.98 \pm 1.81^{\mathrm{b}}$ & \multirow{4}{*}{$0.000^{*}$} & \\
\hline & 12.62 & $54.97 \pm 3.42^{\mathrm{b}}$ & & \\
\cline { 3 - 3 } & 25.25 & $45.01 \pm 3.96^{\mathrm{ab}}$ & & \\
\hline & 50.48 & $25.23 \pm 13.72^{\mathrm{a}}$ & & \\
\hline & & & &
\end{tabular}

*:ANOVA; a: $\mathrm{p}<0.05$, ANOVA followed by post hoc Bonferroni, compared with control;

b: $p<0.05$, ANOVA followed by post hoc Bonferroni, compared with simvastatin $50.48 \mu \mathrm{g} / \mathrm{mL}$.

\section{Apoptosis induction assay}

The apoptosis of T47D breast cancer cell line after incubation with simvastatin is presented in FIGURE 2. Lower left showed live cells population, lower right showed apoptotic cells, and upper right showed necrotic cells.

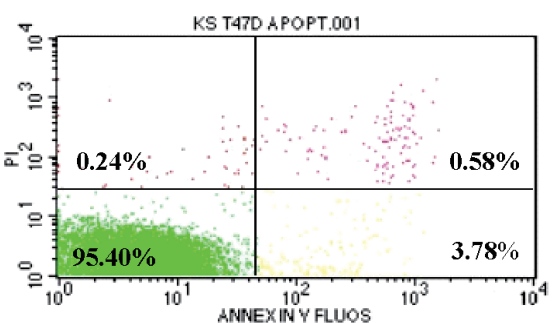

(a)

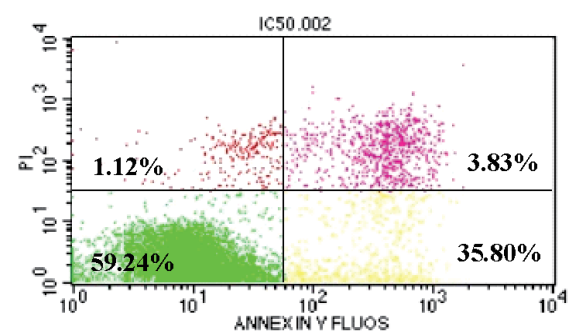

(d)

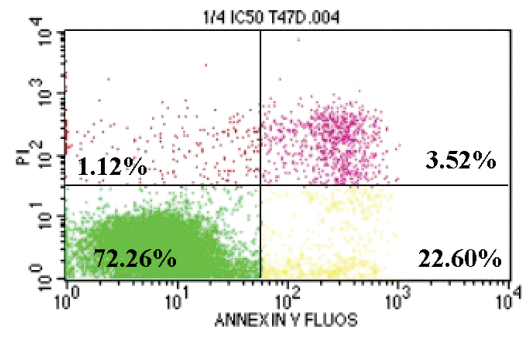

(b)

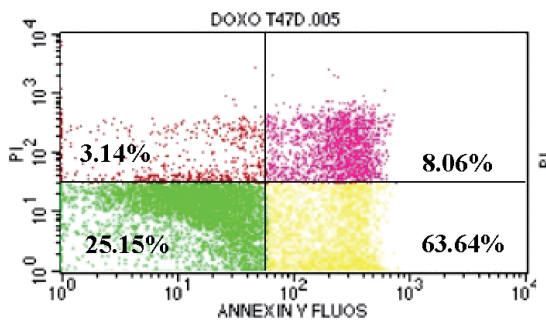

(f)

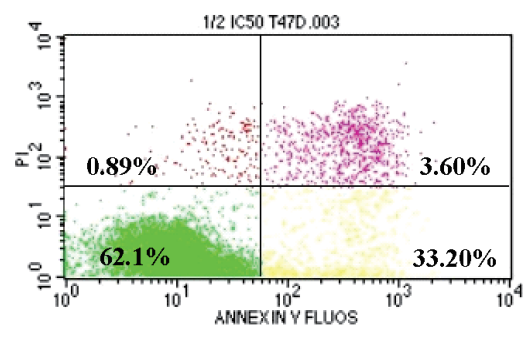

(c)

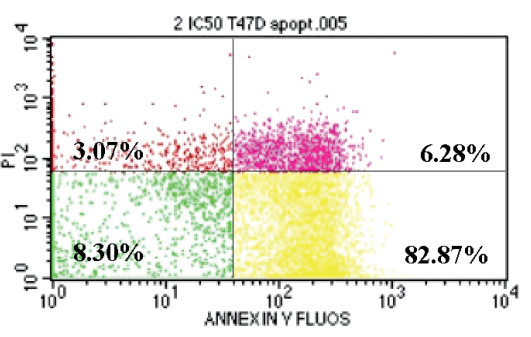

(e)

FIGURE 2. Apoptosis induction measured with flowcytometry after 24 hours incubation in (a) control group without simvastatin, (b) simvastatin $6.31 \mu \mathrm{g} / \mathrm{mL}$, (c) simvastatin $12.62 \mu \mathrm{g} / \mathrm{mL}$, (d) simvastatin $25.25 \mu \mathrm{g} / \mathrm{mL}$, (e) simvastatin $50.48 \mu \mathrm{g} / \mathrm{mL}$, and (f) doxorubicin $0.15 \mu \mathrm{g} / \mathrm{mL}$ as positive control. Lower left: live cells population, lower right: apoptotic cells, upper right: necrotic cells

TABLE 3 shows the T47D breast cancer cells apoptosis after incubation with simvastatin for 24 hours. The simvastatin
$\mathrm{IC}_{50}$ value $(25.25 \mu \mathrm{g} / \mathrm{mL})$ obtained from the cytotoxic activity assay was also used as one of the tested concentration for apoptosis 
assay. Simvastatin increased cells apoptosis in a concentration-dependent manner with the $\mathrm{EC}_{50}$ value of $26.96 \pm 6.05 \mu \mathrm{g} / \mathrm{mL}$.
This finding indicated that incubation with simvastatin induces apoptosis in T47D breast cancer cells.

TABLE 3. Mean of apoptotic cell of T47D cells (\%) after giving simvastatin or doxorubicin for 24 hours

\begin{tabular}{lcccc}
\hline \multicolumn{1}{c}{ Treatment } & $\begin{array}{c}\text { Concentration } \\
(\mu \mathrm{g} / \mathrm{mL})\end{array}$ & $\begin{array}{c}\text { Mean of apoptotic } \\
\text { T47D cells (\%) } \pm \mathrm{SD}\end{array}$ & $\mathrm{p}$ & $\mathrm{EC}_{50}(\mu \mathrm{g} / \mathrm{mL})$ \\
\hline Control & 0 & $4.82 \pm 0.92$ & & \\
Simvastatin & 6.31 & $20.87 \pm 4.55$ & & $26.96 \pm 6.05$ \\
& 12.62 & $19.60 \pm 11.79$ & & \\
& 25.25 & $31.60 \pm 8.62$ & & \\
& 50.48 & $82.39 \pm 0.54^{\mathrm{ab}}$ & & \\
Doxorubicin & 0.15 & $66.94 \pm 2.97^{\mathrm{ab}}$ & & \\
\hline
\end{tabular}

*: ANOVA Test; a: $\mathrm{p}<0.05$, ANOVA continued post hoc Tamhane, compared with control; $\mathrm{b}$ : $\mathrm{p}<0.05$, ANOVA continued post hoc Tamhane, compared with simvastatin $6.31 \mu \mathrm{g} / \mathrm{mL}$.

\section{DISCUSSION}

\section{Cytotoxic activity of simvastatin}

The T47D breast cancer cell lines was used in this study due to its high homogeneity and its simplicity replaceable with frozen stock contamination observed. Therefore these cells are often used for in vitro cancer studies. ${ }^{10}$ The results showed that incubation with simvastatin at concentrations from 50 to $1.5625 \mu \mathrm{g} / \mathrm{mL}(119.45-3.73 \mu \mathrm{M})$ for 24 hours inhibited T47D cell lines proliferation. This finding was consistent with other in vitro studies conducted by some authors. Lee et $a l .{ }^{11}$ showed that incubation with simvastatin at concentrations from 0 to $500 \mu \mathrm{M}(0-209.3$ $\mu \mathrm{g} / \mathrm{mL}$ ) for 24 and 48 hours inhibited the bile duct cancer cells proliferation. The incubation with simvastatin at concentration from 15 to $120 \mu \mathrm{M}(6.27$ to $50.22 \mu \mathrm{g} / \mathrm{mL})$ for 24 and 28 also inhibited lung cancer A549 cells proliferation. ${ }^{12,13}$ Furthermore, Huang et al. 14 reported that incubation with simvastatin at concentration from 2 to $16 \mu \mathrm{M}$ for 2472 hours inhibited the HepG2 and Huh7 cell line growth. The proliferation inhibition of ECC-1 and Ishikawa cell lines were also observed after incubation with simvastatin at concentration from 0.01 to $50 \mu \mathrm{M}(0.0041$ to $20.92 \mu \mathrm{g} / \mathrm{mL}){ }^{15}$

According to American National Cancer Institute (NCI), a compound is considered to have cytotoxic effect on cancer cell lines if its $\mathrm{IC}_{50}$ lower than $50 \mu \mathrm{g} / \mathrm{mL} .{ }^{16}$ Furthermore, a compound could be classified as a very active, active and moderate potential anticancer compound if they have $\mathrm{IC}_{50}$ value $<5,5-10$ and 11-30 $\mu \mathrm{g} / \mathrm{mL}$, respectively. ${ }^{17}$ Based on this criteria, simvastatin with an $\mathrm{IC}_{50}$ value of $25.25 \pm 1.61 \mu \mathrm{g} / \mathrm{mL}$ could be classified as a moderate potential anticancer compound. The $\mathrm{IC}_{50}$ of statin group on several cancer cell lines in different incubation period has been reported in the previous studies. The $\mathrm{IC}_{50}$ of simvastatin on MDM-231, SKBr3 and MCF7 cancerous cell varied from 1.26 to $91 \mu \mathrm{M},{ }^{18}$ whereas on A549 cancerous cells was $45 \mu \mathrm{M}$ and on HeLa cell line was 9.14 $\mu \mathrm{M} .{ }^{12,19}$ Other statin drug, fluvastatin also showed cytotoxic effect against C6 glioma 
cancer cells. ${ }^{18}$ In addition, atorvastatin was active against NCI-H292 cancer cells with an $\mathrm{IC}_{50}$ value of $5.54 \mu \mathrm{g} / \mathrm{mL}^{20}$ and lovastatin was active against MDAMB468 and MDAMB231 cancer cells with $\mathrm{IC}_{50}$ values of $8 \mu \mathrm{g} / \mathrm{mL}$ and $5 \mu \mathrm{g} / \mathrm{mL}$, respectively. ${ }^{21}$

\section{Effect of simvastatin on cyclin $D_{1}$ expression}

Simvastatin decreased cyclin $\mathrm{D}_{1}$ expression of T47D breast cancer cell lines in a concentration-dependent manner (TABLE 2). This finding was similar with study conducted by Liang et al. ${ }^{22}$ which showed that simvastatin at concentration range from 12.5 to $50 \mu \mathrm{M}$ (5.23 to $20.92 \mu \mathrm{g} / \mathrm{mL})$ induced cell cycle arrest of NCI-H460 cancer cells through reduction of cyclin $\mathrm{D}_{1}$ and CDK4 expression and enhancement of P21 inhibitors CKD expression. Simvastatin also decreased cyclin $\mathrm{D}_{1}$ expression and $\mathrm{CDK}$ on hepatocellular cancer cell lines (Hep3B and Huh-7). ${ }^{23}$ Another study reported that simvastatin induced apoptosis in the HepG2 and Huh7 cancer cell lines and its activity was accompanied by inhibition of CDK and cyclin $\mathrm{D}_{1}$, whereas CDK inhibitors p19 and p27 were enhanced. ${ }^{24}$ Other statins such as lovastatin also could affect the cell cycle by decreased cyclin D1-CDK 4 expression and increased p $21^{\mathrm{WAF1/CIP} 1}$ expression on MCF-7 cells. ${ }^{2}$

\section{Apoptosis induction activity of simvastatin}

Simvastatin increased cells apoptosis in a concentration-dependent manner. This finding indicated that simvastatin induced apoptosis in T47D breast cancer cell lines. This finding similar with previous studies conducted by some authors. Gopalan et al. ${ }^{25}$ demonstrated that incubation with simvastatin at concentration range from $0.625-5.0 \mu \mathrm{M}$ for three days induced apoptosis of MCF7 and MDA-MB-231 cancer cell line via activation of JNK/CHOP/DR5 signaling pathway. Ghosh-Choudury et $a l .^{26}$ also demonstrated that simvastatin attenuated the antiapoptotic $\mathrm{Bcl}_{\mathrm{XL}}$ expression and induced depression of phosphatase and tensin homologous (PTEN) expression through $\mathrm{NF \kappa B}$ to inhibit breast cancer growth. In addition, Koyuturk et al. ${ }^{27}$ reported that simvastatin induced apoptosis through involvement of JNK in breast cancer cells independent of their ER or p53 expression status. Simvastatin also suppressed PI3K/Akt/mTOR pathway by enhancing PTEN expression and by further sequentially dephosphorylating downstream cascades including Akt, mTOR, p70S6K, S6RP and 4E-BP1. Furthermore, simvastatin inhibited MAPK/ERK pathway by dephosphorylating sequential cascades such as c-Raf, MEK1/2 and ERK $1 / 2 .{ }^{28}$

\section{CONCLUSION}

Simvastatin shows cytotoxic activity on T47D breast cancer cell lines with an $\mathrm{IC}_{50}$ value of $25.25 \mu \mathrm{g} / \mathrm{mL}$. Furthermore, simvastatin decrease cyclin D1 expression with an $\mathrm{EC}_{50}$ value of $18.96 \mu \mathrm{g} / \mathrm{mL}$, and induce apoptosis with an $\mathrm{EC}_{50}$ value of $26.96 \mu \mathrm{g} / \mathrm{mL}$.

\section{ACKNOWLEDGEMENTS}

Authors would like to thank all technicians for their valuable assistance during laboratory works.

\section{REFERENCES}

1. Kementerian Kesehatan Republik Indonesia. Stop kanker. Jakarta: Pusat Data dan Informasi. Kementerian Kesehatan RI, 2015.

2. Sewester CS, Dombeck C, Olin BR, Kastrup EK, Hebel SK. Drugs facts and comparisons. St Louis MO: Lippincott Co., 2004. 
3. Munawar M, Hartono B, Rifqi S. LDL cholesterol goal attainment in hypercholesterolemia: CEPHEUS Indonesian survey. Acta Cardiol Sin 2013; 29(1):71-81.

4. Graaf MR, Beiderbeck AB, Egberts AC, Richel DJ, Guchelaar HJ. The risk of cancer in users of statins. J Clin Oncol 2004; 22(12):2388-94. http://dx.doi.org/10.1200/ JCO.2004.02.027

5. Cardwell CR, Hicks BM, Hughes C, Murray LJ. Statin use after diagnosis of breast cancer and survival: a population-based cohort study. Epidemiology 2015; 26(1):68-78. http:// dx.doi.org/10.1097/EDE.0000000000000189

6. Horiguchi A, Sumitomo M, Asakuma J, Asano T, Asano T, Hayakawa M. 3-hydroxy3-methylglutaryl-coenzyme a reductase inhibitor, fluvastatin, as a novel agent for prophylaxis of renal cancer metastasis. Clin Cancer Res 2004; 10(24):8648-55. http:// dx.doi.org/10.1158/1078-0432.CCR-04-1568

7. Sanchez CA, Rodriguez E, Varela E, Zapata E, Paez A, Masso FA, et al. Statin-induced inhibition of MCF-7 breast cancer cell proliferation is related to cell cycle arrest and apoptotic and necrotic cell death mediated by an enhanced oxidative stress. Cancer Invest 2008; 26(7):698-707. http://dx.doi. org/10.1080/07357900701874658

8. LeeSK, Kim YC, Song SB, Kim S. Stabilization and translocation of p53 to mitochondria is linked to Bax translocation to mitochondria in simvastatin-induced apoptosis. Biochem Biophys Res Commun 2010; 391(4):1592-7. http://dx.doi.org/10.1016/j.bbrc.2009.12.077

9. Gallelli L, Falcone D, Scaramuzzino M, Pelaia G, D'Agostino B, Mesuraca M, et al. Effects of simvastatin on cell viability and proinflammatory pathways in lung adenocarcinoma cells exposed to hydrogen peroxide. BMC Pharmacol Toxicol 2014; 15:67. http://dx.doi.org/10.1186/2050-651115-67
10. Burdall SE, Hanby AM, Lansdown MR, Speirs V. Breast cancer cell lines: friend or foe? Breast Cancer Res 2003; 5(2):89-95.

11. Lee J, Hong EM, Jang JA, Park SW, Koh DH, Choi MH, et al. Simvastatin induces apoptosis and suppresses insulin-like growth factor 1 receptor in bile duct cancer cells. Gut Liver 2016; 10(2):310-7. http://dx.doi.org/10.5009/ gn115195

12. Kim YS, Seol CH, Jung JW, Oh SJ, Hwang $\mathrm{KE}$, Kim HJ, et al. Synergistic effect of sulindac and simvastatin on apoptosis in lung cancer A549 cells through AKT-Dependent down regulation of survivin. Cancer Res Treat 2015; 47(1):90-100. http://dx.doi. org/10.4143/crt.2013.194

13. Li Y, Fu J, Yuan X, Hu C. Simvastatin inhibits the proliferation of A549 lung cancer cells through oxidative stress and up-regulation of SOD2. Pharmazie 2014; 69(8):610-4.

14. Huang $X$, Ma J, Xu J, Su Q, Zhao J. Simvastatin induces growth inhibition and apoptosis in HepG2 and Huh7 hepatocellular carcinoma cells via upregulation of Notch1 expression. Mol Med Rep 2015; 11(3):23340. http://dx.doi.org/10.3892/ mmr.2014.2976

15. Schointuch MN, Gilliam TP, Stine JE, Han $\mathrm{X}$, Zhou C, Gehrig PA, et al. Simvastatin, an HMG-CoA reductase inhibitor, exhibits anti-metastatic and anti-tumorigenic effects in endometrial cancer. Gynecol Oncol 2014; 134(2):346-55. http://dx.doi.org10.1016/ j.ygyno.2014.05.015

16. Nurani LH, Widyarini S, Mursyidi A. Uji sitotoksik dan uji kombinasi fraksi etil asetat ekstrak etanol akar pasak bumi (Eurycoma longifolia Jack) dan doxorubicin pada sel limfosit. J Trop Pharm Chem 2015; 3(2):13847.

17. Xu YJ, Yip SC, Kosela S, Fitri E, Hana M, Goh SH, et al. Novel cytotoxic polyprenylated xanthones from garcinia gaudichaudii. Org Lett 2000; 2(24):3945-38. http://dx.doi. org/10.1021/ol006730t 
18. Sławińska-Brych A, Zdzisińska B, KandeferSzerszeń M. Fluvastatin inhibits growth and alters the malignant phenotype of the C6 glioma cell line. Pharmacol Rep 2014; 66(1):121-9. http://dx.doi.org/10.1016/j. pharep.2014.01.00221

19. Sadeghi-Aliabadi H, Minaiyan M, Dabestan A. Cytotoxic evaluation of doxorubicin in combination with simvastatin against human cancer cells. Res Pharm Sci 2010; 5(2):12733.

20. Barros ALS, Aguiar JS, Araújo, LCC, Peixoto CA, de Medeiros PL, Catanho MTJA, et al. Synergistic anticancer effects of valproic acid, atorvastatin and pioglitazone in human malignant and murine cells. Afr J Pharm Pharmacol 2014; 8(2):31-39. http://dx.doi. org/10.5897/AJPP2013.3797

21. Klawitter J, Shokati T, Moll V, Christians U, Klawitter J. Effects of lovastatin on breast cancer cells: a proteo-metabonomic study. Breast Cancer Res 2010; 12(2):1-20. http:// dx.doi.org/10.1186/bcr2485

22. Liang YW, Chang CC, Hung CM, Chen TY, Huang TY, Hsu YC. Preclinical activity of simvastatin induces cell cycle arrest in G1 via blockade of cyclin D-Cdk4 expression in non-small cell lung cancer (NSCLC). Int J Mol Sci 2013; 14(3):5806-16. http://dx.doi. org/10.3390/ijms 14035806

23. Lee SJ, Hwang JW, Yim H, Yim HJ, Woo SU, Suh SJ, et al. Synergistic effect of simvastatin plus NS398 on inhibition of proliferation and survival in hepatocellular carcinoma cell line.
J Gastroenterol Hepatol 2014; 29(6):1299307. http://dx.doi.org/10.1111/jgh.12503

24. Relja B, Meder F, Wilhelm K, Henrich D, Marzi I, Lehnert M. Simvastatin inhibits cell growth and induces apoptosis and G0/G1 cell cycle arrest in hepatic cancer cells. Int J Mol Med 2010; 26(5):735-41.

25. Gopalan A, Yu W, Sanders BG, Kline K. Simvastatin inhibition of mevalonate pathway induces apoptosis in human breast cancer cells via activation of JNK/CHOP/ DR5 signaling pathway. Cancer Lett 2013; 329(1):9-16. http://dx.doi.org/ 10.1016/j. canlet.2012.08.031

26. Ghosh-Choudhury N, Mandal CC, GhoshChoudhury N, Ghosh-Choudhury G. Simvastatin induces derepression of PTEN expression via NFkappaB to inhibit breast cancer cell growth. Cell. Signal 2010; 22(5):749-58. http://dx.doi.org/ 10.1016/j. cellsig.2009.12.010

27. Koyuturk M, Ersoz M, Altiok N. Simvastatin induces apoptosis in human breast cancer cells: p53 and estrogen receptor independent pathway requiring signalling through JNK. Cancer Lett 2007; 250(2):220-8. http://dx.doi. org/ 10.1016/j.canlet.2006.10.009

28. Wang T, Seah S, Loh X, Chan CW, Hartman $\mathrm{M}$, Goh BC, et al. Simvastatin-induced breast cancer cell death and deactivation of PI3K/ Akt and MAPK/ERK signalling are reversed by metabolic products of the mevalonate pathway. Oncotarget 2016; 7(3):2532-44. http://dx.doi.org/10.18632/oncotarget.6304. 